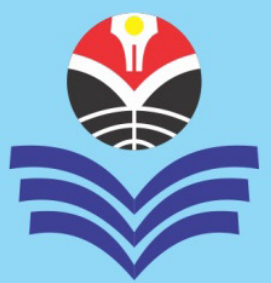

Published every March and September

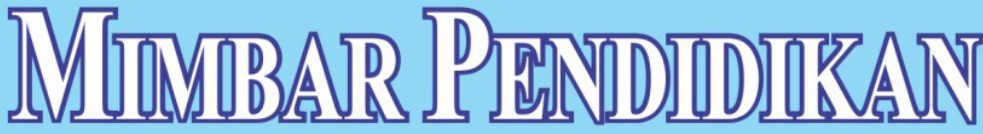

Jurnal Indonesia untuk Kajian Pendidikan

MUHAMMAD WASITH ALBAR

\title{
The Visual Culture of Tolerance in Three Bali's Artworks of Balinese Artist: Putu Sutawijaya, 1998-2010
}

\begin{abstract}
The contemporary life in the era of globalization marked by the fast forward of the tremendous IT (Information Technology). The information discharge excessively needs to have filter to separate the information visually and verbally. This paper studies the culture of tolerance in Balinese artist Putu Sutawijaya, on his three creations, to showed how the spirituality of Hindu's religion promulgate and develop the tolerance figure of his idea as form, which is an assertive spiritual attitude in the name of tolerance in plurality. Every society from a country, including Indonesia, must have a variety of differences, both culture, religion, race, value system, customs, habits, and history. While the spirituality was defined in descriptive analysis, historical anthropologist, and using the Wilhem Dilthey (2010)'s Hermeneutics Theory. The study of cultural tolerance in Putu Sutawijaya case can be found in his three contemporary works: "Fire Sleep for a Moment" in 1998; "In Between" in 2000; and "Solidarity" in 2004. The novelty of this research is an effort to show how the Indonesia's visual culture has a culture and religion tolerance as its main topics.

KEY WORD: Visual Culture; Tolerance; Contemporary Artworks; Putu Sutawijaya.
\end{abstract}

ABSTRAKSI: "Budaya Visual tentang Toleransi dalam Tiga Karya Seni Seniman Bali: Putu Sutawijaya, 19982010". Kehidupan kontemporer di era globalisasi ditandai dengan pesatnya kemajuan IT (Informasi Teknologi). Pembuangan informasi secara berlebihan perlu adanya filter untuk memisahkan informasi secara visual dan verbal. Makalah ini mengkaji budaya toleransi dari seniman Bali Putu Sutawijaya, pada tiga karyanya, untuk menunjukkan bagaimana spiritualitas agama Hindu menyebarluaskan dan mengembangkan sosok toleransi dari gagasannya sebagai wujud, yaitu sikap spiritual yang tegas atas nama toleransi dalam pluralitas. Setiap masyarakat dari suatu negara, termasuk Indonesia, pasti memiliki perbedaan yang beragam, baik budaya, agama, ras, sistem nilai, adat-istiadat, kebiasaan, dan sejarah. Manakala, spiritualitas didefinisikan dalam analisis deskriptif, antropologi sejarah, dan menggunakan Teori Hermeneutika dari Wilhem Dilthey (2010). Kajian tentang toleransi budaya dalam kasus Putu Sutawijaya dapat ditemukan dalam tiga karya seni kontemporernya: "Fire Sleep for a Moment" [Matikan Api Sejenak] pada tahun 1998; "In Between" [Diantara] pada tahun 2000; dan "Solidarity" [Solidaritas] pada tahun 2004. Kebaruan penelitian ini merupakan upaya untuk menunjukkan bagaimana budaya visual Indonesia memiliki budaya dan toleransi beragama sebagai topik utamanya.

KATA KUNCI: Budaya Visual; Toleransi; Karya Seni Kontemporer; Putu Sutawijaya.

About the Author: Muhammad Wasith Albar, M.Hum. is a Lecturer of Art History at the Department of History, Faculty of Humanities UI (University of Indonesia), Depok UI Campus, Depok 16424, West Java, Indonesia. For academic interests, the Author is able to be contacted via e-mail address at: muhammadwasithalbar2000@gmail.com

Suggested Citation: Albar, Muhammad Wasith. (2020). "The Visual Culture of Tolerance in Three Bali's Artworks of Balinese Artist: Putu Sutawijaya, 1998-2010" in MIMBAR PENDIDIKAN: Jurnal Indonesia untuk Kajian Pendidikan, Volume 5(2), September, pp.143-160. Bandung, Indonesia: UPI [Indonesia University of Education] Press, ISSN 2527-3868 (print) and 2503-457X (online).

Article Timeline: Accepted (July 17, 2020); Revised (August 17, 2020); and Published (September 30, 2020). 


\section{INTRODUCTION}

"Everything that was directly lived has moved away into representation" (Guy Debord, 1990).

"The expression of arts help us to taste our recognition for others situation beyond ourself in every subtle process" (Anthony Savile \& Richard Wollheim, 1986).

Researching contemporary art is an activity that is quite interesting and challenging, because the topic of the problem that we want to study is the work of artists, who have contemporary topics. On the other hand, another reason is the reviewer relatively easy to recognize the visual, because the topic of social problems is still so close to the researchers (Zolberg, 1990; Tyler \& Likova, 2012; and Crossick \& Kaszynska, 2018).

But at some point, when we interpreting it, we must be neutral and able to maintain emotional distance to the central theme issues. Remembering contemporary art means "todays art" or "contemporary art". Visual contemporary art substantially has a tendency, which a tradition has a place to be reappointed with a more free theme and media; socio-political themes are common to artists; not disintegrate into high art and low art; characterized by a period of temporaryity; populist art; and reflect the strong local contextuality (Barrett, 1994:109-112; Lughi, 2014; and Upton-Hansen, 2018).

Briefly, as the concept of post-modernism developed as a locomotive for the style of senior visualization, the pluralitymulticultural aspect became the main idiom in the creativity of its artists. Themes that often appear are socio-politics, pluralitymulticultural, environmental, globalization, human rights, violence, and gender bias (Supangkat, 2000:18; Sabana, 2002:18; and Saidi, 2007:18-19) .

When discussing Putu Sutawijaya's three contemporary art works, which will be reviewed in this paper, Putu
Sutawijaya's works have a tendency of showing a social problems, particularly social interaction or social relation encompassing tolerance, conflict resolution, identity problem, and ethnicity. For researchers, the questions can be found if we look at the paintings as a representations of multiculturality $(c f$ Albar, 2012 and 2018; Waruwu, 2017; and Butcher, 2019).

Putu Sutawijaya, born in Tabanan-Bali, $27^{\text {th }}$ November 1971, on his works, like a dancer, he always use a body language gesture as a metaphor (Albar, 2012 and 2018; Waruwu, 2017; and Galikano, 2018). ${ }^{1}$ According to M. Lewandowski (2009), and other scholars, metaphor is a transfer of meanings built upon its form, function, and usability as a consequences of the implicit comparison of two objects (Saidi, 2007; Lewandowski, 2009; and Huang \& Tseng, 2020).

Meanwhile, according to Paul Ricoeur (1991), and other scholars, metaphor is a temporary parable which is undefined permanently. It depends on two things, firstly, the continuous metaphor is made to make meaning; and, secondly, the metaphor not only has emotive value, but also says something new about reality. In other words, metaphors can represent language and signs that can represent the mind of the user in pouring it out as a representation of reality ( $c f$ Ricoeur, 1991; Saidi, 2007:26-28; and Masong, 2012).

Based on the description above, we need to know what is the reasons behind the expression of Putu Sutawijaya on his works through a metaphor of gestures like a dancer? According to Jim Supangkat (2008), and other scholars, Putu Sutawijaya's works, which always questioned dynamic body movements, were a metaphor for the social

\footnotetext{
${ }^{1}$ See also, for example, "Putu Sutawijaya Biography". Available online at: https://pututristi.wordpress. com/2010/10/31/putu-sutawijaya-biography/ [accessed in Depok, West Java, Indonesia: September 2, 2019].
} 
body. The figures of the human body whose existence wander the direction of the wind, want a freedom, and limitless (Supangkat, 2008:7-9; Albar, 2012 and 2018; and Galikano, 2018).

According to Putu Sutawijaya himself, he then stated as follows:

\section{[...] the visualization of gestures indicates} that humans have freedom, but, on the other hand, they remain in the frame of limitations, because they are limited by the freedom of others. Furthermore, humans generally have many and high desires, unfortunately they are many who do not realize their limitations. In fact, sometimes, humans themselves do not know what they really want (cited in Newspaper of Bali Post, on $18^{\text {th }}$ August 2002).

In order to be able to understand the body movement in Putu Sutawijaya's artworks, according to Jim Supangkat (2008), and other scholars, researchers and apresian should understand Sang Hyang's dance philosophy first. Sang Hyang dance from the aspect of religion is one of the guardian dances performed for religious ceremonies. Some say that Sang Hyang dance emerged in the pre-Hindu era, and some say after the entry of Hinduism in Bali. This dance is sacred. Furthermore, the community believes that Sang Hyang dance was effective as a disaster repellent dance, and they still dancing it until now. Sang Hyang dance consists of several types, including: Sang Hyang Bidadari, Sang Hyang Jaran, Sang Hyang Dedeling, and others (Supangkat, 2008:7-9; Albar, 2012 and 2018; and Galikano, 2018). ${ }^{2}$

For Putu Sutawijaya, Sang Hyang dance is believed that the magical world is not only filled with holy spirits and ancestral spirits, but the occult is also inhabited by evil spirits that have destructive power. So, the virtues and policies are at the opposite

\footnotetext{
${ }^{2}$ About "Sang Hyang Dance", see also articles at the website of http://www.parisada.org/index.php [accessed in Depok, West Java, Indonesia: October 2, 2019].
}

poles, namely good and evil. The metaphor of gestures in Putu Sutawijaya's real art works was the frame of Sang Hyang's dance, when the dancers are floating, because they are trance (Kurniawan, 2009; Albar, 2012 and 2018; and Galikano, 2018).

The visualization of floating indicates that there is a battle between evil spirits and holy spirits. A floating body signifies a helplessness of man when facing a life, but Putu Sutawijaya believes that in this battle only sacred forces - noble in the reality will be the winner. Putu Sutawijaya's works that can be observed with Sang Hyang's dance philosophy include: "Fire Sleep for Moment" (140 x $250 \mathrm{~cm}-2$ panels) in 1998a; "In-Between" (200 x $100 \mathrm{~cm})$, in $2000 \mathrm{~b}$; and "Solidarity" (145 x $160 \mathrm{~cm})$ in 2004 (cf Sutawijaya, 1998a, 2000b and 2004; Albar, 2012 and 2018; and Galikano, 2018).

The installation/sculpture works by Putu Sutawijaya in the FIPB UI (Fakultas Ilmu Pengetahuan Budaya, Universitas Indonesia or Faculty of Humanities, University of Indonesia) at the Art Appreciation Park, Depok, West Java, Indonesia, on the "Merasa Bebas" [Feel Free], made in by $2010 \mathrm{~b}$, showed the conceptualization of the gestures of a dancer in Putu Sutawijaya's creative process of exposition. Putu Sutawijaya clearly expressed his artist statement. The expression in his works on the "Merasa Bebas", Putu Sutawijaya conducted a metaphor with the motions of barong dancers. Putu Sutawijaya's artist atatement for the "Merasa Bebas" is following here:

\footnotetext{
Do we need to imagine, there is always a tangible measure to determine what we produce, and of course if an artist, which is clearly in the form of works of art. At the moment I feel, I have become a dancer who is attached by a culture that grow up, buttress, encourages, gives imagination, etc. or vice versa is also made as a binder. The binding here can also be as a language of inability from escaping the past or as a punishment for individuals who are unable to behave.
} 
One motion in the "Barong" dance shows how powerful and expression free, since it is very imaginative and inspires work (feel free). It precisely showed when the performer sweat during the exercise, and not on the sparkly stage with a limited display without showing his greatness and glory is become an attraction itself.

Being present and without having to be uprooted from the past does not mean showing limitations, it can actually be a way of exploring to known limitations and built awareness, it turns out that outside of ourselves must be learned and certainly tried to be realized (Sutawijaya, 2010b:6).

Barong dance is one of the sacred dances originating from pre-Hindu times. Barong dance is believed by Balinese people including Putu Sutawijaya - to drive away evil spirits, various diseases, and all kinds of danger. Barong dance generally depicts the battle between two magic nobles from Bali and Blambangan in East Java. The two figures are Minak Bedewang and Alit Sawung. For no apparent reason, both involved in a great fight. Their battles took a long time. Miraculously no one was hurt. Both of them use powerful and terrifying powers, a big tiger and an eagle. These two embodiments symbolized a tremendous battle. Even though they carried out attacks against each other, both of them showed the same strength. Until the voice appear from the sky ordered them to stop the fight. Finally, the two knights united into a new power. There are many versions of Barong dance in Bali, but the moral obligation remains the same, showed the community to always maintain and carry out the noble attitude of being together. Some versions of the Barong dance include the Barong Kemiren, Barong Ket, Barong Bangkal, Barong Gajah, Barong Landung, and Barong Blasblasan/Kedingkling dances (Supangkat, 2008; Albar, 2012 and 2018; and Galikano, 2018). ${ }^{3}$

\footnotetext{
${ }^{3}$ See also about "Barong Dances", the articles at the
} website of http://www.parisada.org/index.php [accessed in
Wayan Kun Adnyana (2019), and other scholars, argued that Putu Sutawijaya's creative process is always at a distance (recognition) with the Balinese cosmological tradition. Understanding something rather than denying something is an attitude that actually makes an artist can be critical. Putu Sutawijaya married and lived in Yogyakarta, Central Java, Indonesia. Putu Sutawijaya experienced the situation and make him have an ability to absorb, identify, and be able to properly interpreting the traditions of Bali in the era of globalization (glo/go-Balisasi). Some Balinese terms about harmony in the Balinese cosmological tradition, including panelokan (see), paninjoan (gazing), apaneleng (as far as the eye can see), apanimpug (as far as throwing a hand), and so on, are essential ability for the artist to identify related matters with his visibility, pause, and limit (Albar, 2012 and 2018; Galikano, 2018; and Adnyana, 2019). ${ }^{4}$

To analyze the three contemporary artworks of Putu Sutawijaya, I will use the hermeneutics of Wilhelm Dilthey (2010) to understand his creative process and to explain the meaning behind his paintings using the approach of denotation and connotation from Roland Barthes, in 2009, and other scholars; the interview with Putu Sutawijaya on 25-27 October 2012 in Jakarta; and several other relevant study in social sciences ( $c f$ Dilthey \& Jameson, 1972; Christomy, 2004:79-81; Barthes, 2009:158162; Dilthey, 2010; and Interview with Putu Sutawijaya, 25/10/2012, 26/10/2012 and 27/10/2012).

\section{METHODS}

The article is using a qualitativedescriptive research with four stages in historical research, which are heuristics, criticism, interpretation, and historiography (Starman, 2013; Sjamsuddin, 2014;

\footnotetext{
Depok, West Java, Indonesia: October 2, 2019].

${ }^{4}$ See also, for example, Newspaper of KOMPAS. Jakarta: Sunday, $9^{\text {th }}$ January 2011.
} 
and Kim, Sefcik \& Bradway, 2017). Furthermore, to understand the notion of contemporary art, we used D.M. Marianto (2000)'s definition, i.e. contemporary art is a work of art whose ideas are formed and influenced by the reflection of the current situation, wherein "global culture" spawns with a lot of influence. These external factors were also the cause of changes and developments in society. On the other hand, contemporary art is an art that reflects the situation and always changes from modern society to contemporary or present (Marianto, 2000:189-193; Kusumastuti, 2006; and Dirgantoro, 2014).

Moreover, D.M. Marianto (2000), and other scholars, explained the contemporary art was not an art with static idealism, which reject the traditional arts only for its refusal alone. Contemporary art is an ongoing art, it can be witnessed at the present along with the traditional art without any question, because it also has the right to live together. The most important element on the contemporary art is not the rights to speak through the artworks, but how to arrange every element or component messages can be delivered to the audience. The element of the contemporary played a role to representing and transforming the actual present into artworks when the society still discussed about it (Marianto, 2000; Kusumastuti, 2006; and Dirgantoro, 2014).

The most important thing in contemporary art is not the element that is used to speak through works of art, but how can a series of elements or components be conveyed. So, the recent feeling plays a role in the presentation that highlights and transforms the actual problems of the present into works of art, whose discussion reflects the current situation, either is still trending or discussed in the midst of society (Kusumastuti, 2006; Dirgantoro, 2014; and Pelowski et al., 2016).

To understand the meaning of contextuality in a contemporary artwork,
Wilhelm Dilthey (2010), and other scholars, method of hermeneutics (hermeneuein) will be used as interpretation. Hermeneutics is the art of interpreting the meaning of a text in a particular context. It can be said that hermeneutics is a process of changing something through the interpretation of a situation from not knowing into understanding (Dilthey \& Jameson, 1972; Priyanto, 2001; Barthes, 2009; Dilthey, 2010; and Sjamsuddin, 2014).

Emilio Betti (1990) argued, as quoted also by E. Sumaryono (1993) and other scholars, that the task of an interpreter is to clarify the problem to be understood by investigating each stage of the interpretation. An interpreter must not be passive, he/she must always try to reconstruct meaning. Non-census est inferendus sed eferendus, meaning is not taken from conclusions but must be derived (Betti, 1990; Sumaryono, 1993:24 and 28-31; Valauri, 2000; Barthes, 2009; and Prakoso \& Khasanah, 2018).

Wilhelm Dilthey (2010)'s hermeneutics relies on three concepts, namely: Erlebnis, Ausdruck, and Verstehen. Wilhelm Dilthey (2010) focused on our experience of the reality of the historical world, and the nature of our knowledge of the past ( $c f$ Dilthey \& Jameson, 1972; Priyanto, 2001; Barthes, 2009; Dilthey, 2010; and Sjamsuddin, 2014). This is summarized in the phrase, according to F.R. Ankersmit (1987), as following here:

What I am now experiencing, I see in the light of my past, the light I imagine my past depends on the experience of my life that I now get. [...]

There is a reciprocal influence between new and old experiences as true experience or "erlebnis" (Ankersmit, 1987:159 -160).

The parallel connection between the interpretation of the text and the structure of Erlebnis is emphasized by Wilhelm Dilthey (2010), and other scholars' thinking, it can be seen from the way he made the relationship (zusammenhang) between old 
and new experiences towards reciprocal processes. According to Wilhelm Dilthey (2010), "Reality for us is in reality we realized and determined by internal experience". So, an honest contemporary art worker will act and create works based on unity and attachment that are unique to his/her personality or identity. The artist described the reality, which has conformity with appreciation or perception of the surrounding reality ( $c f$ Dilthey \& Jameson, 1972; Priyanto, 2001; Sutrisno, 2005; Dilthey, 2010; and Sjamsuddin, 2014).

From this point, the unity and togetherness finally projected his/her personality out in a certain act, it could be a work of art or in the form of minds, ideas, and concepts. When the results of the process of creation have succeeded as a productive act of art workers, it means that unity and togetherness have climbed at the ausdruck stage (expression). Ausdruck is an objectivation regarding intangibles or erlebnis coherence (Dilthey \& Jameson, 1972; Ankersmit, 1987:161; Priyanto, 2001:126128; Barthes, 2009; and Dilthey, 2010).

Wilhelm Dilthey (2010)'s third concept is verstehen (understand). There are several conditions so that the verstehen process can run well. Firstly, researchers must familiarize themselves with psychic process that allow a meaning to be understood. Secondly, the knowledge of context. Thirdly, researchers must have knowledge of social and cultural systems as determinants of the phenomenon of the object of study. Verstehen is the workings of the cultural sciences, parallel to erklaren (explain), which applies in natural sciences based on general legal patterns (Dilthey \& Jameson, 1972; Ankersmit, 1987:163; Priyanto, 2001:133; Barthes, 2009; and Dilthey, 2010).

Furthermore, the close relation between the structuralist methodology with hermeuneutics shown that the perspective basically emphasizes the interaction or the occurrence of dialectics between individuals (observable) and structures (unobservable) that result in social or historical changes. This perspective assumes ontologically that reality in history is a loosely social structured rather than a tightly social structured from Talcott Parsons (1951). The consequences of it will faced the open social structure that allows the emergence of individuals or social groups, which has a different desires or point of views with the current society and it will trying to change the society (Parsons, 1951; Lloyed, 1993; and Glaeser, 2014).

So, the structural methodology explanation is a determinist, with emphasis on causation derived from the strength of social structures. Whereas structuralist methodology uses humanistic cause and effect, namely the creation of interactions between humans and their social structures (Lloyed, 1993; Leirissa, 1998:9-11 and 1999; and Glaeser, 2014).

How change and continuity in history can be explained by structuralist methodology? Changes that occur in history can be found in actions, historical actors, and events. While continuity, which can take on roles is agency, person, which is part of the social structure. On the other hand, for those who have innovation and motivation to change history through the order in their society, they cannot escape from traditions which are essentially part of the social structure itself (Lloyed, 1993; Leirissa, 1998 and 1999; and Purwanta, Pelu \& Musadad, 2020).

So, a structuralist methodology is a bridge between change and continuity. Because structuralist is a loosely structured, so it allows the community to take a role to maintain the continuity of social structure (reproduction), or vice versa the action taken is to change society (transformation). Individuals or social groups that have the ability to reproduce and change society, in a structured methodology known as the agency. The success of the agency is due to the continuous dialectical results between 
agencies and social structures (Lloyed, 1993:93-95; Leirissa, 1998 and 1999; and Archer, 2010).

Where is the meeting point between structuralist methodology and hermeneutics? The structuralist central point perspective can be found in historical sources. Historical sources were used as an epistemic access, in order to reveal the relationship between the agency and the social structure. On the other hand, historical sources can also reveal the expressed intentions, the goals expressed through works or writings, from the agency. This component, in the other designation, is known as mentalite, which is someone's expression of him/her-self and his/her world (Lloyed, 1993; Leirissa, 1998 and 1999; and McCulloch, 2004).

To be able to use the expressed intention of the actors, thoughts and events properly and correctly, the apresian/interpreter must have the ability, skill, and foresight of the historical method, so that historical reconstruction (mentalite) and meaning can be in line as desired by historical actors. The best procedure for executing and realizing it is the hermeneutic approach (understanding and appreciation), so that events, historical actors, and their intentions (common interest) can be revealed and to be displayed to the surface (McCulloch, 2004; Hansen, 2014; and Tilden, 2017).

This desire is in line with the opinion of Wilhelm Dilthey (2010), as cited also in F.R. Ankersmit (1987), and other scholars, thar if someone is able to reconstruct the life experience of a history actor on the inner stage of the historical researcher (the appreciator of the work), the inner stage of the historical researcher will be reproduced, the same effect as before with the perpetrator of history. When a historical researcher has reconstructed, in his/her own mind, the experiences of an agent, while using his/her own life experience, he/she is able to verstehen the actions and thoughts of the agency (Dilthey \& Jameson,
1972; Ankersmit, 1987:162; Barthes, 2009; Dilthey, 2010; and Tilden, 2017).

\section{RESEARCH RESULTS AND DISCUSSION}

Before we analyze the three paintings by Putu Sutawijaya, this is a brief biography of the solo exhibition of the artist Putu Sutawijaya: (1) "Contemplation" in Gajah Gallery, Singapore, in 1995; (2) "Energi" in Bentara Budaya Yogyakarta, Indonesia, in 1998a; (3) "Energy" in Gajah Gallery, Singapore, in 1999a; and "Organ" in Lembaga Indonesia-Perancis, Yogyakarta, Indonesia, in 1999b; (4) "Matikan Api, Tidurlah Sejenak" in Sika Gallery, Ubud, Bali, Indonesia, in 2000d; "Energy-2" in Chouniard Gallery, Hong Kong, in 2000a; "Kamar dan Ilusi Tubuh" in Canna Gallery, Jakarta, Indonesia, in 2000c; and "Ritus Tubuh" in Galeri Danes Art Veranda, Denpasar, Bali, Indonesia, in 2000e; (5) "Dance with Line" in Gallery Hotel, Singapore, in 2005; (6) "Body-O" in Valentine Wille Fine Art, Malaysia, in 2006; (7) "Fullmoon" in Sin Sin Fine Art, Hong Kong, in 2007; (8) "Man Mountain" in CIGE, Beijing, China, in 2008b; and "Legacy of Sagacity" in National Gallery, Jakarta, Indonesia, in 2008a; (9) "Gesticulation" in Bentara Budaya Jakarta, Indonesia, in 2010a; (10) "Remembering" in Sin Sin Art, Hong Kong, in 2014; (11) "Betwixt and Between" in LATAR, BTPN Sinaya, CBD Mega Kuningan, Jakarta, Indonesia, in 2017; and (12) "Earth Scape" in Can's Gallery, Tanah Abang II No.25, Jakarta, Indonesia, in 2018 (cf Sutawijaya, 1995, 1998a, 1999a, 1999b, 2000a, 2000c, 2000d, 2000e, 2005, 2006, 2007, 2008a, 2008b, 2010a, 2014, 2017, and 2018; Albar, 2012 and 2018; and Interview with Putu Sutawijaya, 25/10/2012). See, then, picture 1.

The work of "Fire Sleep for a Moment" narrates the desire of Putu Sutawijaya (1998b) to the general public, so that they have a strong tolerance towards various 
deviations carried out by the community in expressing euphoria at the beginning of reform in Indonesia. At this time, almost all Indonesian artists made concurrent work that was based on political issue. They have massive works that narrate profanity and blame the actions of President Soeharto regime, which they labeled a lot of deviations and abuse of power. Only a small number of artists who brought up the reason behind the fall of the New Order regime (19661998), while expecting a better system of government to occur in the future, the Reformation

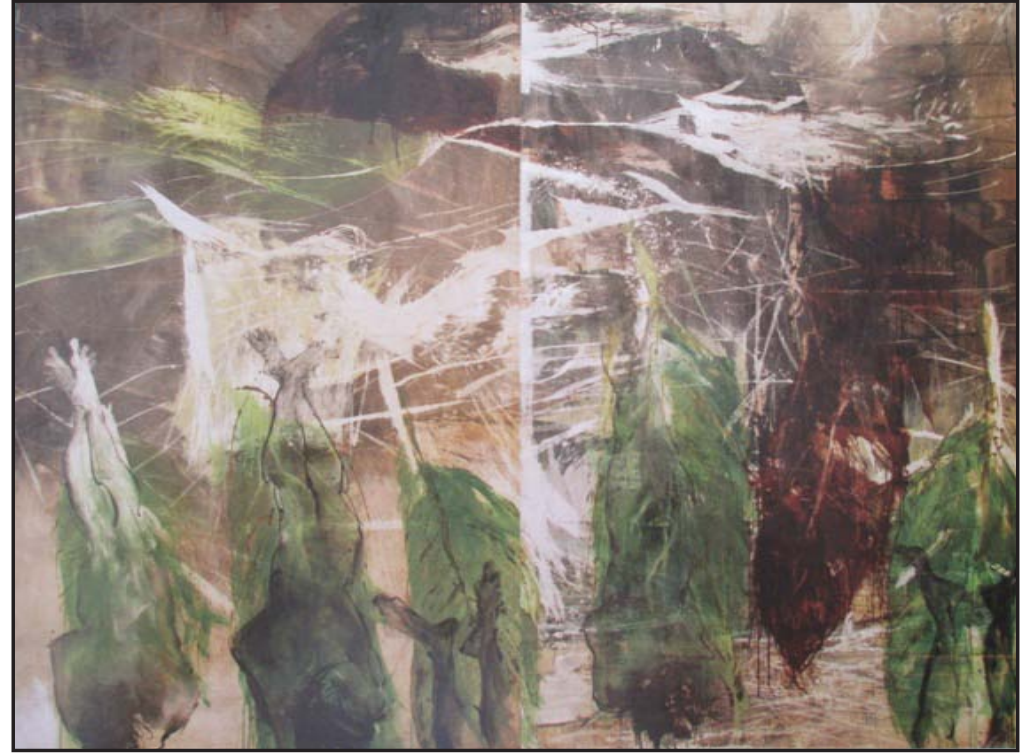

Picture 1:

"Fire Sleep for a Moment" (140 x $250 \mathrm{~cm}$ - 2 panel), Mixced Media on Canvas, by Putu Sutawiaya, in 1998b
Era in 1998 ( cf Sutawijaya, 1998b; Albar, 2012 and 2018; and Interview with Putu Sutawijaya, 26/10/2012).

At least there are optimistic themes came from an artist, which is Putu Sutawijaya (1998b), who choose a theme of expecting the general public to maintain unity by prioritizing tolerance (understanding and accepting differences). A noble attitude from Balinese artists who always prioritize tolerance and contemplation. Various other themes that fulfill the art-world, including some works that narrate the improvement in all lines of people's lives; eliminate discrimination; cooperate with various elements of the nation; end conflicts; uphold plurality; eliminate KKN (Korupsi, Kolusi, dan Nepotisme or Corruption, Colussion, and Nepotism); human rights issues; and various other issues, such as arbitrary actions, injustice, and the closure of various social, economic, and political channels (Sutawijaya, 1998b; Mulya, 2012; Armini, 2013; Albar, 2012 and 2018; and Interview with Putu Sutawijaya, 26/10/2012).

The painting on "Fire Sleep for a Moment" has a narrative that pushing all elements of the nation to encourage taking a position by seeing the social reality of Indonesia is very plural. Multiculturalism attitude, in order for the country to be peaceful without any action that can divide them, it will stop conflict and chaos. Negative behavior, prejudice, and nagging against those of different races and religions, must immediately be removed from everyone. The reaction of chaos that took place during the birth of the 1998 Reformation hurts every parts of the national elements, both material and immaterial victims. The riots in economic center in some cities that lead to burned a lot of economic center paralyzed the national economy, while immaterial victims are more damaged than material victims (Sutawijaya, 1998b; Albar, 2012 and 2018; and Interview with Putu Sutawijaya, 27/10/2012).

According to some studies, there have been found hypotheses that there are victims of rape from certain ethnicities, some Indonesia refugees go to foreign countries, and the emergence of mutual suspicion lately between the elements of the nation that are quite prolonged, and other psychological trauma from the 1998 chaos. 
In particular, psychological trauma for young children, when they witnessed that their families were victims of the May 1998 riots in the early Reform era (Hamid et al., 2005; Albar, 2012 and 2018; and Purwanti \& Prabowo, 2018).

The indexical "Matikan Api" (Turn of the Fire)" used by Putu Sutawijaya, by using leaf symbolization, is a way to turn off fire (conflict and various riots), which is usually done by our society. Traditional ways to turn off fire by beating fire with fresh or green leaves often occur in rural communities. Whereas in urban communities, to turn off fires blazing in their kitchens they cover fire with a soaked towel. They not water the fire. If they choose it action, then, the fire (conflict/riot) will be even bigger (Sutawijaya, 2000d; Albar, 2012 and 2018; and Interview with Putu Sutawijaya, 27/10/2012).

Putu Sutawijaya deliberately chose the language of green leaf metaphor (a towel soaked in water), both of are have cold elements, so the fire will soon die. When the public is emotionally high to express reform euphoria, Putu Sutawijaya calmly and maturely does not participate in overflowing excitement, but he chooses to uncover the teachings of his beliefs by carrying out contemplative attitudes a lonely road, but all the essential messages of human life are to continue to tolerate (Sutawijaya, 2000d; Albar, 2012 and 2018; and Interview with Putu Sutawijaya, 27/10/2012).

This symbolization implies the action of a powerless society. To be able to "turn off the fire", the message from Putu Sutawijaya's painting is that various elements of the nation are expected to cooperate with each other. It starts from itself and the immediate environment to turning off the fires of conflict, have a mutual trust, erasing prejudice between ethnic groups, so that the fire will not grow and will quickly die. According to Putu Sutawijaya, with the magnitude of the fire that keeps burning/ undoubtedly, the fire will not only devour something labeled as an enemy, but fire will also devour someone who inflames hostility itself. Both of them will not be winners, but both are losers (Sutawijaya, 2000d; Albar, 2012 and 2018; and Interview with Putu Sutawijaya, 27/10/2012).

For those who have power can do "extinguish the fire" through various instruments of the institution where they, as commanders or within their jurisdiction, for example by "extinguish the fire", by taking social control measures from military/police officers, and other law enforcement. But, the real action of the presence of the state was not immediately felt by the people, because the state administrators were not trusted by their people. The cause is prolonged multidimensional crisis (Morgera \& Cirelli, 2009; Ajidarma, 2012; and Albar, 2012 and 2018).

The "Fire Sleep for a Moment" painting consists of two panels. Both of them still have remnants of fire that are burning, but not enlarged depicting smoky fire wrapping in a circles form. From various experiences of social conflict or social unrest, the threat of the onset of a latent conflict situation will still be present, a fire that keeps burning small, which gives rise to smoke (Sutawijaya, 1998b; Albar, 2012 and 2018; and Interview with Putu Sutawijaya, 26/10/2012).

On the other hand, Putu Sutawijaya made a metaphor of six green leaves, there is one leaf that has been "burned". The philosophy is that every element of the nation must act quickly to "turn off the fire" (end the conflict) with the "sleep for a moment"; then, Putu Sutawijaya's suggestion an effort to destructively minimize it, so that it can be presented soon (Sutawijaya, 1998b and 2000d; Albar, 2012 and 2018; and Interview with Putu Sutawijaya, 26/10/2012).

Putu Sutawijaya (1998b and 2000d), and other scholars, stated that we often hear a credo "every revolution will eat its own 
children"; and "Elephants fights, then, the ants will be victims". The rulling class is in conflict, so the people will always be miserable. The point is pluralistic messages, multiculturalism, and tolerance are always voiced by Putu Sutawijaya through his paintings. The problem is how to manage diversity, differences, and conflicts. Putu Sutawijaya does not reduce diversity to the extent of ethnicity, but he tries to voice that diversity also occurs in the realm of economics, politics, belief, education, and others by doing the great work that confronts us all as a large, intrinsically metaphoric nation in "Fire Sleep for a Moment" painting ( $c$ Sutawijaya, 1998b

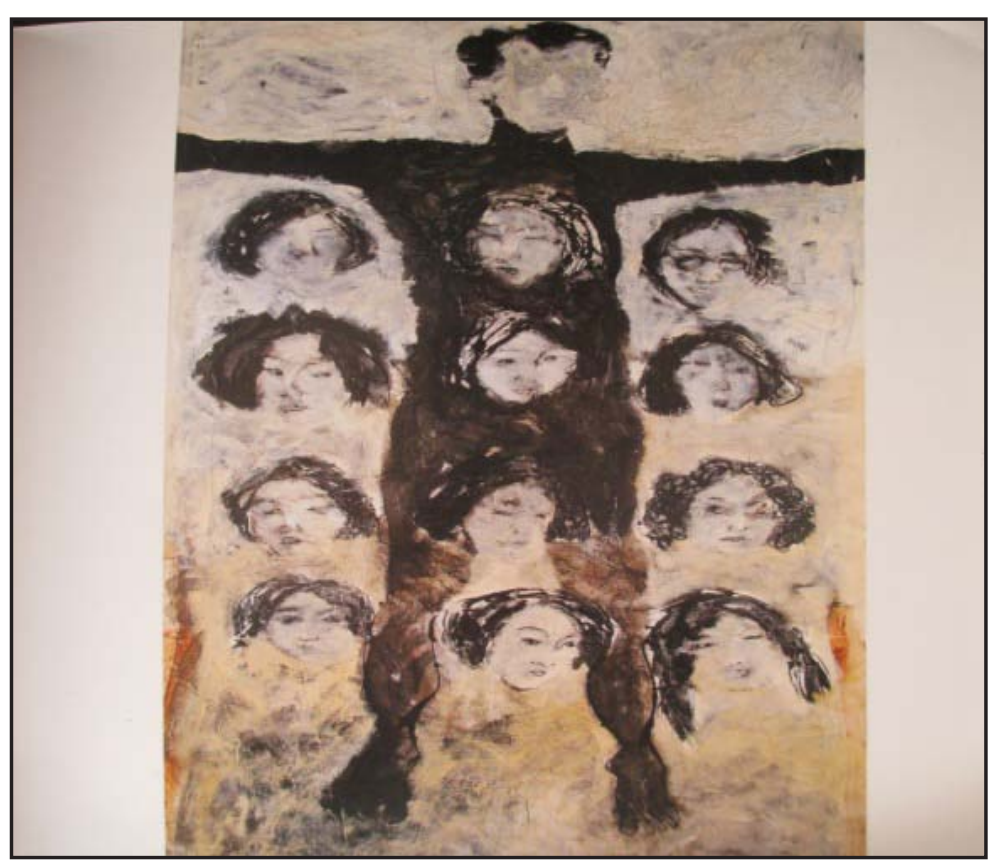

Picture 2:

"In Between" (200 x 100 cm), Mixced Media on Canvas, by Putu Sutawijaya, in 2000 b

to the occurrence of interactions (both men and women) with those who happen to have a light skin tone (yellow). The interaction is not only limited to the issue of communication and working together in the existing social order, but it can be further than that: a man with dark skin (black) is not likely to be able to marry light-skinned women (yellow). Even if we look visually at the man (black) who is manly and confident, surrounded by angels (Sutawijaya, 2000b; Albar, 2012 and 2018; and Interview with Putu Sutawijaya, 25/10/2012).

In this context, Putu Sutawijaya was, then, explaining and emphasizing as follows: obedient, so good women must have smooth skin (white/yellow), with the profession as housewife. In short, skin color can also be indicative of social classes in society (cf Sutawijaya, 2000b; Albar, 2012 and 2018; and Interview with Putu Sutawijaya, 25/10/2012).

"In-Between" painting, according to Putu Sutawijaya, is a phenomenon that dark skin color (black) does not become a barrier
The experience in our society, if the phenomenon occurs then the parameters are no longer dark black skin, but the man should be suspected of having a character that is indeed liked by many women. In a semiotic way that black has the meaning and, of course, grandeur, charismatic, and calm. For patriarchal people, this black man is identical to a responsible man and a hard worker, who will bring prosperity and happiness to 
the women, or family members, around him (Interview with Putu Sutawijaya, 26/10/2012).

The visualization of "In-Between" painting, there is one tall, handsome man, with a large posture and dark skin in "among" nine light-skinned women (nymphs). The closeness of the man with the angels shown that there are nine angels in his scope yet, there are three angels who fill in the individual (heart) of the man. A construction of patriarchal interpretation that places a man as a super hero, the holder of power, has excessive freedom which is permissible to dominate some women (nymphs) at once in a certain period in the lives of men (Sutawijaya, 2000b; Albar, 2012 and 2018; and Interview with Putu Sutawijaya, 26/10/2012).

Furthermore, if we take a closer look at the paintings above, there are nine female faces with different face shapes, namely oval, oval, and round with different jaw shapes. There are those who have eye glasses and not with different nose shapes. Different hair characters, there are straight and curls. Having different hairstyles, namely short career style women, long unraveling like famous models, bobbing models wearing spoiled girl-style bangs, half-standing hairstyles in the style of punk singers, and there are also reggae-style curls. A "diversity" that is a trend among urban youth (Sutawijaya, 2000b; Albar, 2012 and 2018; and Interview with Putu Sutawijaya, 26/10/2012).

A metaphor that the message of social interaction in a multicultural, plural society, and the era of globalization, or "glo/gobali-sasi", must be based on the principles of egalitarianism and mutual respect, by prioritizing tolerance not in discourse, but in everyday reality as the fashionable style of life model. Must be brave enough to take a position that can be accepted by many people, accommodating other people's opinions, even though they are different in many ways or SARA (Suku, Agama, Ras, Antargolongan or Ethnic, Religion, Race, and Groups). Such as fashionable influences (also culinary) which are not separated by SARA differences. But, all actors and connoisseurs (producer agencies and consumers) approach each other to find common ground to strengthen pleasure services. A metaphor for what this reality can be done in the lives of our people. Certainly a nation and state's life will have peace ( $c f$ Hall, 1990; Sutawijaya, 2000b; Albar, 2012 and 2018; Pamungkas, 2014; and Berenschot, Nordholt \& Bakker eds., 2017).

Back to skin color, hair shape, eye shape, nose, and race origin, Putu Sutawijaya is intended that is no longer a limitation of discrimination or segregation in interacting with fellow citizens in a nation or between one nation and another in this world. The phenomenon of the occurrence of mixed marriages between nations has actually happened as a daily life in our society (how the Islamization occurred). Hypothetically, it is said that we all have a long origin that we have "blood offspring" from various nations, including the peoples of India, China, the Middle East, and Europe ( $c f$ Sutawijaya, 2000b; Albar, 2012 and 2018; and Purnama, 2020).

It is just that such a tremendous diversity is not well managed by the people or state. In particular, countries from time to time only take the wrong action of perpetuating various policies that reduce the vulnerability to the realm of cultures, not to the true meaning of diversity. We need to educate character to the people: how is it that since childhood all elements of the nation want to understand and accept that the various differences "among" other differences are blessing; so, grace is not a disaster (Sutawijaya, 2000b; Matsuura, 2009; Albar, 2012 and 2018; Pamungkas, 2014; and Saifuddin, 2017).

The deepest meaning of "In-Between" painting is the desire of the artist, Putu 
Sutawijaya, so that we can all be able to uphold plurality, difference, and diversity that exist in the community (nation) must be seen as a power that is able to strengthen the unification of the national elements. The expectations that we should reflect at any time will succeed if the pragmatic order of reality in our society practices tolerant behavior towards fellow elements of the nation. A tolerant attitude by promoting these inclusive values in the political conception is called the human qua citizen - a citizen.

Fellow citizens must have a desire to develop mutual, mutual trust, and mutual commitment. Thus, the life of the nation which is characterized by solidarity and shared commitment can increase tolerance and high multicultural values (Sutawijaya, 2000b; Albar, 2012 and 2018; Baghi, 2012:8-9; Karim, 2016; and Interview with Putu Sutawijaya, 26/10/2012).

Remembering the creative process of this painting as a result of the chaos stimulus in May 1998, every amok (chaos) event in our society, the meaning of "In-Between" painting always has relevance as an artifact that reminds us all to jointly organize life "among" we are better off without any desire to mutually respect each other or be heroic to win victory in selfishness (Sutawijaya, 2000b; Ohmae, 2002; Albar, 2012 and 2018; and Interview with Putu Sutawijaya, 26/10/2012). See, then, picture 3.

"Solidarity" painting, as shown in the picture 3 , is a simple phrase and has often been heard by someone from the lowest to highest class. "Solidarity" can be positive and negative. Both depend on the problems faced, so that someone takes and determines the attitude of solidarity that is carried

Picture 3:

"Solidarity" (145 x $160 \mathrm{~cm}$ ), Mixced Media on Canvas, by Putu Sutawijaya, in 2004

out. "Solidarity" practiced in activities that violate social norms and the law will certainly produce solidarity that has a negative impact, and vice versa (Loomba, 2003; Sutawijaya, 2004; Albar, 2012 and 2018; and Interview with Putu Sutawijaya, 25/10/2012).

Visualization of paintings on "Solidarity" is a response to the events of the second presidential election in a period of conflict full of conflict by showing the ugliness of each group with a different choice from the candidate pair, or PASLON (Pasangan Calon or Candidate Pair), of the President-Vice President. "Solidarity" painting contains a very wise and noble message to the rulling class that is asked to work hand in hand (cooperate), prioritize mutual assistance or mutual cooperation, strengthen the unification, and help those who weak or powerless by helping them; and this is for those who have the capital/ power (elite). Dynamic visualization of gestures shows the many social problems that exist. The dexterity of footsteps shows a situation of precarious conditions (Salmi, 
2003; Sutawijaya, 2004; Albar, 2012 and 2018; and Interview with Putu Sutawijaya, 26/10/2012).

The issue of solidarity is our work as elements of the nation. The desire to change itself in quick pace and keep moving very visible, almost all of the soles of the feet are not tread on the ground and some are just the tips of the toes that touch the ground like ballet dancers. This visualization gives meaning to something that must be quickly dealt with, right away with a proper execution, precarious situation, and an urgency (Geertz, 1973; Heryanto ed., 2008; Matsuura, 2009; and Albar, 2012 and 2018).

Likewise, the step that are not in the same direction shows many problems in the beginning of this reformation. Reflex hand swings indicate that there are optimism in the people, who want to hold their hands together and unite, so that the amok and chaos problems in May 1998 will not happen again and the situation can return to normal conditions as before the May 1998 riots. Hope still on its brims, and according to Putu Sutawijaya's intuition, it can only be created if there is solidarity by promoting tolerance (Sutawijaya, 2004; Fine \& Ellis, 2010; Albar, 2012 and 2018; Imarmata, 2017; and Interview with Putu Sutawijaya, 27/10/2012).

The human body (male) that is vaguely created by the painter as a metaphor, so that it can be displayed universally for the owner of social problems. A face that is deliberately painted abstract does not represent a particular group in our society (Geertz, 1973; Sutawijaya, 2004; Kymlicka, 2010; Albar, 2012 and 2018; and Dirgantoro, 2014). In this context, finally, Putu Sutawijaya stated as following here:

We discuss in the realm of problem solving. This anonymous figure can represent anyone, the artist's own figure with his closest environment, can be yours, can me, or anyone as an agent of change or vice versa. Concentrate on the forms of cooperation, mutual help, reassurance, respect, commitment, trust, and some inherited values from our ancestors (inheritance of intelligence). If this inclusive attitude is played by all elements of our nation, surely Indonesia will become a great nation that is respected and valued by other nations in this world (Interview with Putu Sutawijaya, 27/10/2012).

\section{CONCLUSION $^{5}$}

Three works of art - "Fire Sleep for a Moment", "In-Between", and "Solidarity" - of Putu Sutawijaya speaks of the representation (depiction) of pluralistic, multicultural, and tolerance attitudes that must always be instilled and reminded in every element of Indonesia, to both those who have no power and the rulling class. Putu Sutawijaya, who highly respects the values of Balinese traditions (teachings of Hinduism), is able to raise the issue of pluralism, multiculturalism, and tolerance through visual culture using the metaphor of the movements of dancers of Sang Hyang, Barong, and Rajah Bali. For Putu Sutawijaya that pluralism, multiculturalism, and tolerance are three elements that exist in every nation and must always be stirred up, reminded that the third element is the most important element (tolerance) as a cohesive tie to the unity and unity of a great identity of a nation.

Every society from a country must have a variety of differences, both culture,

\footnotetext{
${ }^{5}$ An Acknowledgment: This article, before being repaired again and re-edited as in its current form, was presented in the ICHE (International Conference on History Education), organized by the Study Program of History Education SPs UPI (School of Postgraduate, Indonesia University of Education) in Bandung, West Java, on Thuesday, $25^{\text {th }}$ June 2019. I would like to thank the ISHE Committee for allowing this article to be published in the journal of MIMBAR PENDIDIKAN; and also high appreciation goes to Andi Suwirta, M.Hum., Senior Lecturer at the Department of History Education FPIPS (Faculty of Social Studies Education) UPI in Bandung, West Java, Indonesia, who helped re-edit this article, especially in updating and completing Bibliography or References. However, all contents and interpretations of this article remains the responsibility of me academically, and has nothing to do with the assistance they have given me.
} 
religion, race, value system, customs, habits, and history. Cultural diversity and difference is a necessity that occurs in a large current of contemporary-globalization. This phenomenon must be welcomed as a blessing, because the three elements above will provide mental readiness and knowledge for every element of the nation, how to manage conflict, promote tolerance in every interaction, and the emergence of a wise attitude that must be corrected from time to time and updated, so that it raises new meaning in every social interaction, in the international level of association.

In the research of three contemporary Putu Sutawijaya's artworks, it has been found that Putu Sutawijaya always consistent in his concept and has full authority in his creative process, where ideas are a form in conveying his message that plural; and multicultural society is really how a micro-macro-global community culture; and community is able also to see, understand, reach, accept, and exclude a difference that exists. Considering differences is a necessity in all parts of life of mankind in this world; and tolerance is so determinant as an element that has an important role as a cohesiveness of a dynamic but harmonious society. ${ }^{6}$

\section{References}

Adnyana, Wayan Kun. (2019). "Overview of the Bali Art Infrastructure”. Available Online At: Https:// Lifeasartasia.Art/Tag/Dr-Wayan-Kun-Adnyana/ [accessed in Depok, West Java, Indonesia: March 9, 2020].

\footnotetext{
${ }^{6}$ Statement: I certify that this article is an original result of my academic work. This is not plagiarism, because the sources I refer to or quote, either directly or indirectly, are clearly listed full in the Bibliography or References. This article has never been sent, reviewed, and published by other scientific journals, so it is specifically published by the journal of MIMBAR PENDIDIKAN in Bandung, West Java, Indonesia. I am ready to accept academic sanctions, if what I declare, turns out to be at a later date, violates existing rules and regulations.
}

Ajidarma, Seno Gumira. (2012). Antara Tawa dan Bahaya: Kartun dalam Politik Humor. Jakarta: Penerbit KPG [Kepustakaan Populer Gramedia]. Albar, Muhammad Wasith. (2012). "Representasi Multikulturalisme dan Globalisasi dalam Tujuh Karya Seni Rupa Kontemporer Putu Sutawijaya, 1998-2010” in Prosiding Seminar Internasional Multikultural dan Globalisasi. Available online also at: https://multikulturalui.files.wordpress. com/2013/05/prosiding-simg-ui-2012-jilid-2-08. pdf [accessed in Depok, West Java, Indonesia: October 2, 2019].

Albar, Muhammad Wasith. (2018). "Visualisasi Kesunyian Seni Rupa Kontemporer Putu Sutawijaya dalam Kuratorial Betwixt and Between, 2017" in Prosiding Seminar Nasional Agama, Adat, Seni, dan Sejarah di Zaman Milenial. Available online also at: https://press. unhi.ac.id/wp-content/uploads/2018/09/14. pdf [accessed in Depok, West Java, Indonesia: October 2, 2019].

Ankersmit, F.R. (1987). Refleksi tentang Sejarah: Pendapat-pendapat Modern tentang Filsafat Sejarah. Jakarta: PT Gramedia, terjemahan Dick Hartoko.

Archer, Margaret S. (2010). "Morphogenesis Versus Structuration: On Combining Structure and Action" in BJS: The British Journal of Sociology, Vol.61, Iss.1. Available online also at: https:// onlinelibrary.wiley.com/doi/full/10.1111/j.14684446.2009.01245.x [accessed in Depok, West Java, Indonesia: October 16, 2019].

Armini, I Gusti Ayu. (2013). "Toleransi Masyarakat Multi-Etnis dan Multi-Agama dalam Organissi Subak di Bali" in PATANYALA, Vol.5, No.1 [Maret].

Baghi, Felix. (2012). Pluralisme, Demokrasi, dan Toleransi. Maumere: Ledalero.

Barrett, Terry. (1994). Criticizing Art: Understanding the Contemporary. California, London, and Toronto: Mayfield Publishing Company. Available online also at: https://pdfs.semanticscholar.org/3 5f5/50763b8b83fd733914cdf719b6ae356cb1b4. pdf [accessed in Depok, West Java, Indonesia: October 2, 2019].

Barthes, Roland. (2009). Mitologi. Jogjakarta: Kreasi Wacana, Translation.

Berenschot, W., H. Schulte Nordholt \& L. Bakker [eds]. (2017). Citizenship and Democratization in Southeast Asia: Social, Economic, and Political Studies of the Middle East and Asia, Volume 115. Leiden: Brill. Available online also at: https://doi. org/10.1163/9789004329669 [accessed in Depok, West Java, Indonesia: October 17, 2019].

Betti, Emilio. (1990). "Hermeneutics as the General Methodology of the Geisteswissenschaften" in Gayle L. Ormiston \& Alan D. Schrift [eds]. The 
Hermeneutic Tradition: From Ast to Ricoeur: Albany: SUNY [State University of New York] Press, translated by Josef Bleicher, pp.159-197.

Butcher, Henry. (2019). "Art + Architecture Auction". Available online at: http://hbart.com. my/files/AAJUNE19-web.pdf [accessed in Depok, West Java, Indonesia: March 2, 2020].

Christomy, Tommy. (2004). Semiotika Budaya. Depok: Penerbit PPKB Universitas Indonesia.

Crossick, Geoffrey \& Patrycja Kaszynska. (2018). "Understanding the Value of Arts \& Culture: The AHRC Cultural Value Project". Available online at: https://ahrc.ukri.org/documents/publications/ cultural-value-project-final-report/ [accessed in Depok, West Java, Indonesia: October 2, 2019].

Debord, Guy. (1990). Treatise on Secrets: Commentaires sur la Societe du Spectacle. London: Verso.

Dilthey, Wilhelm. (2010). Selected Works, Volume IV: Hermeneutics and the Study of History. New Jersey: Princeton University Press, revised edition.

Dilthey, Wilhelm \& Frederic Jameson. (1972). "The Rise of Hermeneutics" in New Literary History, Vol.3, No.2 [Winter], pp.229-244. Published by the Johns Hopkins University Press.

Dirgantoro, Wulandani. (2014). "Defining Experiences: Feminisms and Contemporary Art in Indonesia". Unpublished Ph.D. Thesis. Australia: Asian Languages and Studies Program, School of Humanities, University of Tasmania. Available online also at: https://core.ac.uk/download/ pdf/33334942.pdf [accessed in Depok, West Java, Indonesia: October 9, 2019].

Fine, Gary Alan \& Bill Ellis. (2010). The Global Grapevine: Why Rumors of Terrorism, Immigration, and Trade Matter. Oxford and New York: Oxford University Press.

Galikano, Silvia. (2018). "Putu Sutawijaya dan Spektrum Spiritual Karyanya" in SARASVATI: Art Communication \& Publication, on May 12. Available online also at: https://sarasvati.co.id/ artist/05/putu-sutawijaya-dan-spektrum-spiritualkaryanya/ [accessed in Depok, West Java, Indonesia: October 2, 2019].

Geertz, Clifford. (1973). The Interpretation of Cultures: Selected Essays. New York: Basic Books, Inc. Puhlishers.

Glaeser, A. (2014). "Hermeneutic Institutionalism: Towards a New Synthesis" in Qualitative Sociology, Volume 37, pp.207-241. Available online also at: https://doi.org/10.1007/s11133014-9272-1 [accessed in Depok, West Java, Indonesia: October 17, 2019].

Hall, Stuart. (1990). "Cultural Identity and Diaspora" in Jonathan Rutherford [ed]. Identity: Community, Culture, Difference. London: Lawrence \& Wishart.
Hamid, Usman et al. (2005). Menatap Wajah Korban: Upaya Mendorong Penyelesaian Hukum Kejahatan Terhadap Kemanusiaan Dalam Peristiwa Kerusuhan Mei 1998. Jakarta: Solidaritas Nusa Bangsa.

Hansen, Chloe. (2014). "Theatrical Interpreting: An Explanation of the Process" in Honors Senior Theses/Projects, No.15. Available online also at: https://digitalcommons.wou.edu/honors theses/15 [accessed in Depok, West Java, Indonesia: October 17, 2019].

Heryanto, Ariel [ed]. (2008). Popular Culture in Indonesia: Fluid Identities in Post-Authoritarian Politics. London and New York: Routledge. http://www.parisada.org/index.php [accessed in Depok, West Java, Indonesia: October 2, 2019].

Huang, K.C. \& M.Y. Tseng. (2020). "The Creative Use of Defeat is Control in Metaphors for Sport: A study of NBA Headlines Written in Chinese" in Journal of Language and Linguistic Studies, Volume 16(1), pp.14-29. doi:10.17263/ jlls. 712632 .

Imarmata, Henry Thomas. (2017). Indonesia: Zamrud Toleransi. Jakara: Penerbit PSIK [Pusat Studi Iskan dan Kenegaraan] Indonesia.

Interview with Putu Sutawijaya, in Jakarta, Indonesia, on $25^{\text {th }}$ October 2012.

Interview with Putu Sutawijaya, in Jakarta, Indonesia, on $26^{\text {th }}$ October 2012.

Interview with Putu Sutawijaya, in Jakarta, Indonesia, on $27^{\text {th }}$ October 2012.

Karim, M. Abdul. (2016). "Toleransi Ummat Beragama di Desa Loloan, Jembrana, Bali: Ditinjau dari Perspektif Sejarah" in ANALISIS, Vol.XVI, No.1 [Juni].

Kim, H., J.S. Sefcik \& C. Bradway. (2017). "Characteristics of Qualitative Descriptive Studies: A Systematic Review" in Research in Nursing \& Health, Volume 40(1), February, pp.23-42. Available online also at: https://www. ncbi.nlm.nih.gov/pmc/articles/PMC5225027/ [accessed in Depok, West Java, Indonesia: October 9, 2019].

Kurniawan, Heru. (2009). Mistisisme Cahaya. Yogyakarta: Grafindo Literatur Media.

Kusumastuti, Yuliana. (2006). "Market Forces: A Case Study of Contemporary Art Practice in Indonesia". Unpublished M.A. Thesis. Australia: Faculty of Law, Business, and Arts, Charles Darwin University. Available online also at: [accessed in Depok, West Java, Indonesia: October 9, 2019].

Kymlicka, W. (2010). Kewarganegaraan Multikultural. Jakarta: Penerbit LP3ES, translated by A. Salam.

Leirissa, R.Z. (1998). Strukturisme dalam Ilmu 
Sejarah: Pengantar. Jakarta: Program Ilmu Sejarah PPs UI [Program Pascasarjana, Universitas Indonesia].

Leirissa, RZ. (1999). Metodologi Strukturis dalam Ilmu Sejarah. Jakarta: Program Ilmu Sejarah PPs UI [Program Pascasarjana, Universitas Indonesia].

Lewandowski, M. (2009). "Metaphors from Other Sports in the Language of Soccer: Evidence from English and Polish" in P. Nowak \& P. Nowakowski [eds]. Język, Komunikacja, Informacja [Language, Communication, Information]. Poznań: Sorus, pp.29-48.

Lloyed, Christoper. (1993). The Structure of History. London: Basil Blackwell.

Loomba, Ania. (2003). Kolonial/Pasca Kolonial. Yogyakarta: Bentang Pustaka, Translation.

Lughi, Giulio. (2014). "Digital Media and Contemporary Art" in MJ: Mimesis Journal, Volume 3(2), pp.43-52. Available online also at: https://journals.openedition.org/mimesis/686 [accessed in Depok, West Java, Indonesia: October 2, 2019].

Marianto, D.M. (2000). "Recognising New Pillars in the Indonesian Art World" in B. Huangfu [ed]. Text and Subtext Contemporary Art and Asian Woman: Earl Lu Gallery. Singapore: LASALLESIA, College of the Arts, pp.139-145.

Masong, Kenneth. (2012). "Metaphor, Poiesis, and Hermeneutical Ontology: Paul Ricoeur and the Turn to Language" in Pan Pacific Journalof Philosophy, Education, and Management, Vol.1, No.1, pp.1-7. Available online also at: https:// philpapers.org/archive/masmpa-4.pdf [accessed in Depok, West Java, Indonesia: October 9, 2019].

Matsuura, Koïchiro. (2009). UNESCO World Report: Investing in Cultural Diversity and Intercultural Dialogue. Paris, France: UNESCO [United Nations Educational, Cultural, and Scientific Organization]. Available online also at: https:// www.un.org/en/events/culturaldiversityday/pdf/ Investing_in_cultural diversity.pdf [accessed in Depok, West Java, Indonesia: October 17, 2019].

McCulloch, Gary. (2004). Documentary Research in Education, History, and the Social Sciences. London and New York: Routledge Falmer.

Morgera, Elisa \& Maria Teresa Cirelli. (2009). Forest Fires and the Law: A Guide for National Drafters Based on the Fire Management Voluntary Guidelines. Rome: Food and Agriculture Organization of the United Nations. Available online also at: http://www.fao.org/3/a-i0488e. pdf [accessed in Depok, West Java, Indonesia: October 17, 2019].

Mulya, Rudiaji. (2012). Feodalisme dan Imperialisme di Era Globalisasi. Jakarta: Elex
Media Komputindo.

Newspaper of Bali Post, on $18^{\text {th }}$ August 2002.

Newspaper of KOMPAS. Jakarta: Sunday, $9^{\text {th }}$ January 2011.

Ohmae, Kenichi. (2002). Hancurnya NegaraBangsa: Bangkitnya Negara Kawasan dan Geliat Ekonomi Regional di Dunia Tak Terbatas. Yogyakarta: Penerbit Qalam, Translation.

Pamungkas, Cahyo. (2014). “Toleransi Beragama dalam Praktik Sosial: Studi Kasus Hubungan Mayoritas dan Minoritas Agama di Kabupaten Buleleng" in EPESTEME, Vol.9, No.2 [Desember].

Parsons, Talcott. (1951). The Social System. New York: The Free Press.

Pelowski, M. et al. (2016). "Visualizing the Impact of Art: An Update and Comparison of Current Psychological Models of Art Experience" in Frontiers in Human Neuroscience, Volume 10:160 [April]. Available online also at: https://www.ncbi.nlm.nih.gov/pmc/articles/ PMC4844603/ [accessed in Depok, West Java, Indonesia: October 9, 2019].

Prakoso, T. \& V. Khasanah. (2018). “Understanding the Core Ideas of Hermeneutics Figures". Paper for the $1^{\text {st }}$ International Seminar on Language, Literature, and Education, published by $\mathrm{KnE}$ Social Sciences, pp.702-711. DOI:10.18502/kss. v3i9.2733.

Priyanto, Supriyo. (2001). Wilhelm Dilthey: Peletak Dasar Ilmu-ilmu Humaniora. Semarang: Penerbit Bendera.

Purnama, I.Y. (2020). "The Meaning of Color and its Symbol of Strength in the Exhibition 17/71: Goresan Juang Kemerdekaan" in KnE Social Sciences: International Conference on Art, Design, Education, and Cultural Studies, pp.590599. DOI:10.18502/kss.v4i12.7633.

Purwanta, Hieronymus, Musa Pelu \& Akhmad Arif Musadad. (2020). "Developing Continuity-Based History Learning Material: An Alternative" in Journal of Critical Reviews, Vol.7, Iss.3, pp.307-312. Available online also at: http:// www.jcreview.com/fulltext/197-1583819425.pdf [accessed in Depok, West Java, Indonesia: May 20, 2020].

Purwanti, Ani \& Rian Adhivira Prabowo. (2018). "Women Rights Fulfillment as the Victim of Gross Human Rights Violation: Urgency for the Sexual Violence Eradication Bill" in Indonesia Law Review, Volume 3, pp.303-315. Available online also at: https://media.neliti. com/media/publications/272383-none-5b13ad2f. pdf [accessed in Depok, West Java, Indonesia: September 16, 2019].

"Putu Sutawijaya Biography". Available online at: https://pututristi.wordpress.com/2010/10/31/putu- 
sutawijaya-biography/ [accessed in Depok, West Java, Indonesia: September 2, 2019].

Ricoeur, Paul. (1991). From Text to Action: Essays in Hermeneutics, Volume II. London: Athlone, translated by Kathleen Blamey \& John B. Thompson.

Sabana, S. (2002). "Spiritualitas dalam Seni Rupa Kontemporer di Asia Tenggara: Indonesia, Malaysia, Thailand, dan Filipina sebagai Wilayah Kajian". Unpublished Doctoral Dissertation. Bandung: PPs [Program Pascasarjana] Seni Rupa FSRD ITB [Fakultas Seni Rupa dan Desain, Institut Teknologi Bandung].

Saidi, Acep Iwan. (2007). "Narasi Simbolik dalam Seni Rupa Kontemporer Indonesia”. Unpublished Doctoral Dissertation. Bandung: PPs [Program Pascasarjana] Seni Rupa FSRD ITB [Fakultas Seni Rupa dan Desain, Institut Teknologi Bandung].

Saifuddin, Achmad Fedyani. (2017). "Five Letters that 'Hurt': The Multicultural Indonesia in Current Faster Change Era" in Asia Pacific Journal of Advanced Business and Social Studies, Vol.3, Iss.2. Available online also at: https:// apiar.org.au/wp-content/uploads/2017/07/15 APJABSS v3i2 Social-Sciences-168-175. pdf [accessed in Depok, West Java, Indonesia: September 16, 2019].

Salmi, Jamil. (2003). Kekerasan dan Kapitalisme: Pendekatan Baru dalam Melihat Hak-hak Azasi Manusia. Yogyakarta: Pustaka Pelajar.

Savile, Anthony \& Richard Wollheim. (1986). "Imagination and Pictorial Understanding" in Proceedings of the Aristotelian Society: Supplementary Volumes, Volume 60, pp.19-60. Published by Oxford University Press.

Sjamsuddin, Helius. (2014). Metodologi Sejarah. Yogyakarta: Penerbit Ombak.

Starman, Adrijana Biba. (2013). "The Case Study as a Type of Qualitative Research" in Journal of Contemporary Educational Studies, Volume 1, pp.28-43.

Sumaryono, E. (1993). Hermeneutik: Sebuah Metode Filsafat. Yogyakarta: Penerbit Kanisius.

Supangkat, Jim. (2000). "Dimana Letak Yogyakarta dalam Peta Seni Rupa Kontemporer Indonesia” in Outlet 2000. Yogyakarta: Yayasan Cemeti.

Supangkat, Jim. (2008). Legacy of Sagacity. Jakarta: Galeri Canna-Galeri Nasional Indonesia.

Sutawijaya, Putu. (1995). "Contemplation” in Gajah Gallery, Singapore.

Sutawijaya, Putu. (1998a). "Energi" in Bentara Budaya Yogyakarta, Indonesia.

Sutawijaya, Putu. (1998b). "Fire Sleep for a Moment" (140 x $250 \mathrm{~cm}-2$ Panels), Mixced Media on Canvas.

Sutawijaya, Putu. (1999a). "Energy” in Gajah
Gallery, Singapore.

Sutawijaya, Putu. (1999b). "Organ” in Lembaga Indonesia-Perancis, Yogyakarta, Indonesia.

Sutawijaya, Putu. (2000a). "Energy-2" in Chouniard Gallery, Hong Kong.

Sutawijaya, Putu. (2000b). "In-Between" (200 x 100 $\mathrm{cm})$, Mixced Media on Canvas.

Sutawijaya, Putu. (2000c). "Kamar dan Ilusi Tubuh" in Canna Gallery, Jakarta, Indonesia.

Sutawijaya, Putu. (2000d). "Matikan Api, Tidurlah Sejenak” in Sika Gallery, Ubud, Bali, Indonesia.

Sutawijaya, Putu. (2000e). "Ritus Tubuh" in Galeri Danes Art Veranda, Denpasar, Bali, Indonesia.

Sutawijaya, Putu. (2004). "Solidarity" (145 x 160 $\mathrm{cm})$, Mixced Media on Canvas.

Sutawijaya, Putu. (2005). "Dance with Line" in Gallery Hotel, Singapore.

Sutawijaya, Putu. (2006). "Body-O” in Valentine Wille Fine Art, Malaysia.

Sutawijaya, Putu. (2007). "Fullmoon" in Sin Sin Fine Art, Hong Kong.

Sutawijaya, Putu. (2008a). "Legacy of Sagacity" in National Gallery, Jakarta, Indonesia.

Sutawijaya, Putu. (2008b). "Man Mountain" in CIGE, Beijing, China.

Sutawijaya, Putu. (2010a). "Gesticulation" in Bentara Budaya Jakarta, Indonesia.

Sutawijaya, Putu. (2010b). "Merasa Bebas" [Feel Free] in Catalog. Depok: UI [University of Indonesia] Art Appreciation Park.

Sutawijaya, Putu. (2014). "Remembering" in Sin Sin Art, Hong Kong.

Sutawijaya, Putu. (2017). "Betwixt and Between" in LATAR, BTPN Sinaya, CBD Mega Kuningan, Jakarta, Indonesia.

Sutawijaya, Putu. (2018). "Earth Scape” in Can's Gallery, Tanah Abang II No.25, Jakarta, Indonesia.

Sutrisno, Mudji. (2005). Teks-teks Kunci Estetika Filsafat Seni. Jakarta: PT Agro Media Pustaka.

Tilden, Freeman. (2017). Interpreting Our Heritage. Chapel Hill USA [United States of America]: The University of North Carolina Press, third edition.

Tyler, C.W. \& L.T. Likova. (2012). "The Role of the Visual Arts in Enhancing the Learning Process" in Frontiers in Human Neuroscience, Volume 6:8 [February]. Available online also at: https://www. ncbi.nlm.nih.gov/pmc/articles/PMC3274761/ [accessed in Depok, West Java, Indonesia: October 2, 2019].

Upton-Hansen, Christopher. (2018). “The Financialization of Art: A Sociological Encounter". Unpublished Ph.D. Thesis. London: The Department of Sociology, the London School of Economics and Political Science. Available online also at: http://etheses.lse.ac.uk/4012/1/ Upton-Hansen_Financialization-art_Redacted. 
pdf [accessed in Depok, West Java, Indonesia: October 2, 2019].

Valauri, John T. (2000). “Interpretation, Critique, and Adjudication: The Search for Constitutional Hermeneutics" in Chicago-Kent Law Review, Vol.76, No.1083. Available online also at: https:// scholarship.kentlaw.iit.edu/cklawreview/vol76/ iss2/13 [accessed in Depok, West Java, Indonesia: October 9, 2019].

Waruwu, Dermawan. (2017). "Kawasan Puja Mandala: Wujud Toleransi Bali”. Paper presented in the National Seminar on Philosophy, on March 17.

Zolberg, Vera L. (1990). Constructing a Sociology of the Arts. New York: Cambridge University Press. 